NBER WORKING PAPER SERIES

\title{
TOBACCO SPENDING AND ITS CROWD-OUT OF OTHER GOODS
}

\author{
Susan H. Busch \\ Mireia Jofre-Bonet \\ Tracy A. Falba \\ Jody L. Sindelar \\ Working Paper 10974 \\ http://www.nber.org/papers/w10974 \\ NATIONAL BUREAU OF ECONOMIC RESEARCH \\ 1050 Massachusetts Avenue \\ Cambridge, MA 02138 \\ December 2004
}

The views expressed herein are those of the author(s) and do not necessarily reflect the views of the National Bureau of Economic Research.

(C) 2004 by Susan H. Busch, Mireia Jofre-Bonet, Tracy A. Falba, and Jody L. Sindelar. All rights reserved. Short sections of text, not to exceed two paragraphs, may be quoted without explicit permission provided that full credit, including (C) notice, is given to the source. 
Tobacco Spending and its Crowd-Out of Other Goods

Susan H. Busch, Mireia Jofre-Bonet, Tracy A. Falba, and Jody L. Sindelar

NBER Working Paper No. 10974

December 2004

JEL No. I1

\begin{abstract}
$\underline{\text { ABSTRACT }}$
Smoking is an expensive habit. Smoking households spend, on average, more than $\$ 1000$ annually on cigarettes. For households in which some members smoke, smoking expenditures crowd-out other purchases, which may affect other household members, as well as the smoker. We empirically analyze how expenditures on tobacco crowd out consumption of other goods, estimating the patterns of substitution between tobacco products and other expenditures. We use the Consumer Expenditure Survey (1995 to 2001), which we complement with regional price data, and state cigarette prices. We estimate a consumer demand system of expenditures on cigarettes, food, alcohol, housing, apparel, transportation, medical care and controls for socio-economic variables and other sources of observable heterogeneity. Descriptive data indicate that, compared to non-smokers, smokers spend less on housing. Results from the demand system indicate that as the price of cigarettes rises, households increase the quantity of food purchased, and, in some samples, reduce the quantity of apparel and housing purchased
\end{abstract}

Susan H. Busch

PO Box 208034

Yale School of Public Health

New Haven, CT 06520

susan.busch@yale.edu

Mireia Jofre-Bonet

London School of Hygiene and Tropical Medicine

London School of Economics

m.jofre-bonet@1se.ac.uk
Tracy A. Falba

PO Box 208034

Yale School of Public Health

New Haven, CT 06520

tracy.falba@yale.edu

Jody L. Sindelar

PO Box 208034

Yale School of Public Health

New Haven, CT 06520

and NBER

jody.sindelar@yale.edu 


\section{Introduction}

Smoking is an expensive habit. When a family member quits, in addition to the former smokers' improved long term health, families benefit because savings from reduced cigarette expenditures can be allocated to other goods (CBO, 1990). For households in which some members continue to smoke, indirect effects of smoking include the crowd-out of other purchases, which may affect other household members, as well as the smoker. Information on the adverse health effects of smoking, regulations that increase the cost of smoking (e.g. smoking bans), and rising cigarette taxes have all reduced the percentage of smokers in the US. As more individuals quit smoking or never begin, the benefits in terms of increased consumption of other goods may be substantial, particularly for low income families. In this paper, we explore this often ignored benefit of quitting that accrues to both smokers and their family.

Our concern about forgone consumption relates to the much larger line of literature on cigarette taxes (Chaloupka and Warner, 2000). Cigarette taxation is considered one of the most powerful policy instruments in reducing smoking rates. Extensive resources have been allocated to understanding the direct effect of taxes on reducing tobacco use. Yet, almost no empirical research has attended to the indirect effects of increased taxes on other purchases.

A substantial body of previous research has found that as taxes increase, tobacco consumption declines (Chaloupka and Warner, 2000). Research indicates that this decline comes about equally from prevalence effects (quits or non-initiation) and consumption effects (Farrelly and Evans, 1998). For those who quit or cut back significantly, additional other goods and services may be purchased. These additional goods (e.g., better housing in a lower crime neighborhood, insurance coverage) may have benefits that accrue in addition to the direct effect of smoking cessation on the smoker's health. For those who continue to smoke at a similar rate, 
more may be spent on tobacco than before the tax increase. The latter effect furthers concern about the regressivity of cigarette taxes (Remler, 2004), although research indicates that lower income, minority and younger populations are more likely than others to quit smoking in response to price increases (Farrelly and Bray, 1998). Thus it is important to understand how higher cigarette prices, and thus higher expenditure on tobacco for some, impact expenditure patterns. These expenditure changes will be especially critical for those low-income households whose members continue to smoke.

We provide a framework to document this indirect cost of smoking by analyzing the spending patterns of US families. Specifically, we are interested in which goods households forgo in order to smoke, and thus could potentially gain from quitting. We use the United States Bureau of Labor Statistics' (BLS’) Consumer Expenditure Survey (CES) from 1995 to 2001, to document cigarette and other expenditures for US households. These data have been used before to study the impact of tax credits and tax refunds on spending allocation (Barrow, 1999; Souleles, 1999). Complementing the CES with regional BLS price data and state cigarette prices, we estimate a consumer demand system that includes several main expenditure categories (i.e., cigarettes, food, alcohol, housing, apparel, transportation, medical care) and controls for socio-economic variables and state fixed effects. Our approach uses the Almost Ideal Demand System (AIDS; Deaton, 1980a; Deaton and Muellbauer, 1980b) which provides a method to quantify these effects and has been used in other health applications (Hunt, 1994). Jones (1989) has previously used aggregate expenditure data to estimate the cross price elasticity of four categories of alcoholic drinks and tobacco. We estimate own and cross price elasticities for cigarettes and the other budget categories using individual household data. In some analyses, we focus on low income households or households in which at least one person smokes. By focusing 
on smokers, we can glean some additional information about those who continue to smoke following increases in price.

The empirical analyses presented in this paper concern the United States. During the time period considered here there were significant increases in U.S. cigarette prices, and these varied in amount and time of implementation across states. This variation is critical to estimating the effect of changing cigarette prices. Although we focus on the US, expenditures on tobacco may have greater negative crowd out impact in other countries (Wang, 2004). While tobacco consumption is falling in the US, it is rising rapidly in low and middle income countries (WHO, 2004; MacKay and Erickson, 2002) The approach used in this paper can be applied to other countries in which the impact of smoking on household budgets may be even more critical due to lower income, higher prevalence rates, and heavier smoking.

We find that comparing smoking with non-smoking households, cigarette expenditures appear to crowd-out housing expenditures. Examining cigarette price changes, our estimates of Marshallian (uncompensated) own and cross price elasticity are consistent with the literature, although our own tobacco price elasticity estimates are larger than consensus estimates $(\varepsilon=-.74$ to -.98$)$. We also find that food and tobacco are substitutes. In all samples, as cigarette prices increase, food expenditures increase. This is suggestive of the documented association between smoking cessation and weight gain. Finally, we find that, in some samples, as the price of cigarettes rises, households reduce the quantity of housing and apparel purchased.

\section{Methods}

\section{Data:}


The Consumer Expenditure Survey (CES) is a survey of households collected by the Bureau of Labor Statistics yearly since 1980 (US DOL, 1999). We consider the years 1995 through 2001. The CES interviews selected households a total of 4 times, at 3-month intervals. At each of these interviews, the household is asked detailed questions regarding expenditures during the past 3 months. Each year about 7,000 households are surveyed. Although respondents are not asked about their smoking status, information on tobacco expenditures is collected. Because the CES includes state identifiers, state level variables can be merged to complement these data.

Variables collected in the CES include detailed information at the household level on income, expenditures, composition of household, demographics (e.g., gender, age, education and race), and whether the head of household owns the home. Through both a diary and interview survey, very detailed information on all expenditures in the household is collected. This includes detailed information about housing, food, transportation, health care, entertainment, personal care products, reading, and education.

\section{Analysis:}

Data on tobacco expenditures is collected in two categories: 1) cigarettes and 2) cigars, pipe tobacco and other tobacco products. Thus, households can be categorized as smoking or non-smoking based on whether the household reported expenditures on any smoking supplies. Our preliminary research indicates that according to this algorithm, in the year 2000, 27.6 percent of CES households were classified as smoking households. The CDC's Behavioral Risk Factor Surveillance System indicates that, in 2000, 23.2 percent of Americans smoke (CDC, 2000). Given that there are two or more adults in many households, these numbers are consistent. Our analysis indicates that in 2000, 29.1 percent of poor households smoked. That 
more low-income households are classified as smoking is also consistent with other research (BRFSS, 2000).

We eliminate all observations for which complete income information is not reported, for which information on the state is not available and those for which there is more than one consumer unit in the household. The BLS suppresses state identifiers in some states for confidentiality purposes. We also only consider households where the household head is between the ages of 18 and 64. Our final sample has 91,486 observations. Demographic characteristics of the sample are noted in Table 1.

$<<$ Insert Table 1 about here>>

We calculate average expenditures for each of the eight expenditure categories considered for all households, and then separately by household smoking status. ${ }^{1}$ Because we are interested in the burden of tobacco spending on low income households, we also separately consider these households. ${ }^{2}$ To better understand allocation of resources across goods and because the total expenditures are slightly different within the smoking and non-smoking samples, we also calculate the budget share. Because total expenditures differ among households, the sum of all expenditure categories for all households divided by the sum of all spending for all households does not equal the average of individual households expenditure share.

\footnotetext{
${ }^{1}$ Representative items in expenditure categories include food: food at home, food away from home; housing: rent, mortgage interest, property taxes, maintenance and repairs, utilities, household operations, house furnishings; apparel: mens, boys, womens, girls apparel, footwear, other apparel services; transportation: vehicle purchases (both new and used), gas, motor oil, vehicle finance charges, insurance, repairs, vehicle rentals; health care: health insurance, medical supplies, medical services, prescription drugs. For further specific classifications, see US DOL, 2002.

${ }^{2}$ Low income is defined as less than 200 percent of the US federal poverty line.
} 
We supplement the CES data with price data. For most expenditure categories, price data come from the Bureau of Labor Statistics. Price indexes are created by BLS by commodity, category and region. For example, a separate monthly housing price index is created for the Northeast, Midwest, South and West regions of the United States. Data on cigarette prices are available at the state level for each year of our analysis. In many states, there have been large changes in cigarette prices over the time period we consider. The heterogeneity of the dates and magnitude of these price changes across states is critical to the identification strategy.

To study the substitution and complementation patterns between smoking items and other expenditure categories, we estimate household demand using the Almost Ideal Demand System. The AIDS (Deaton and Muellbauer, 1980) gives an arbitrary first-order approximation to any demand system that is consistent with the notion of scarcity (by which individuals are forced to make choices) and satisfies the axioms of individual choice. Using data on expenditures and prices we estimate a consumer demand system that includes several main expenditure categories (cigarettes, food, apparel, transportation, medical care and alcohol). This system of demand equations relates the budget shares of various commodities (e.g, cigarettes, housing, food) to real total expenditures and relative prices. Thus, using this strategy, one can estimate the own price elasticity, the income elasticity, and all cross-price elasticities of all commodities included in the model. Because the CES data include demographic information, we are able to control for socioeconomic variables and other sources of observable heterogeneity. We estimate this system for all households, all low-income households, and all smoking households.

We estimate the following equation for the budget share of each $i$-th expense category of household $l$ :

$$
w_{i l}=\alpha_{i}+\sum_{j=1}^{n} \gamma_{j i} \ln p_{j}+\beta_{i} \ln \left(\frac{C_{l}}{P_{l}}\right)+\delta_{i} Z_{i l}+\lambda \text { state }_{l}+\phi \text { quarter }_{l}+\varepsilon_{i l}
$$


where $\mathrm{i}$ is the expenditure category, 1 is the household, $\mathrm{w}_{i l}$ is the share of household l's total expenditure spent on $\mathrm{i}, \mathrm{j}$ indexes the expenditure categories such that $\mathrm{pj}$ is the price of category $\mathrm{j}$, $\mathrm{C}_{1} / \mathrm{P}_{1}$ is the total real expenditure on all goods in the consumer's budget; $\mathrm{Z}_{\mathrm{il}}$ is a set of exogenous variables describing the household- $l$ characteristics; and state and quarter represent state and quarter fixed effects.

The above equation is estimated for all $\mathrm{N}$ categories of goods considered. The demand system involves seemingly unrelated regressions (SUR), but since the regressors are the same for all product categories, the generalized least square estimator for the unrestricted model reduces to the application of OLS to each equation separately. ${ }^{3}$ Once the parameters are estimated, the own and cross price elasticities between the expenditure categories chosen can be calculated as follows ${ }^{4}$ :

$$
\begin{aligned}
& \varepsilon_{i i}=\frac{\gamma_{i i}}{w_{i}}-\beta_{i}-1 \quad\left(\text { own }- \text { price elasticity }: i^{\text {th }} \text { good }\right) \\
& \varepsilon_{i j}=\frac{\gamma_{i j}}{w_{i}}-\beta_{i} \frac{w_{j}}{w_{i}} \quad\left(\text { cross }- \text { price elasticity }: i^{\text {th }} \text { good } \text { with respect to } j^{\text {th }} \text { good - price }\right)
\end{aligned}
$$

\section{Results}

The descriptive data indicate that expenditures on cigarettes are not trivial (Table 2). For smoking households, average expenditures on tobacco products were nearly 4 percent of total expenditures, and over $\$ 1000$ annually. For those in low income households, cigarette spending was roughly similar to that spent on out of pocket health care expenditures (\$1056) or apparel (\$1138). Also interesting, in the all income and low income sample, smokers spent roughly the

\footnotetext{
${ }^{3}$ In work in progress, we are exploiting the longitudinality of the dataset and control for the correlation of the error terms over time.

${ }^{4}$ Note that given the formula for the elasticities, we can obtain their variances (and statistical level of significance) as a linear combination of the variances of the estimated coefficients.
} 
same annual amount on smoking (\$1036 versus \$1018), which is in contrast with the fact that most other expenditure categories increase with income.

$<<$ Insert Table 2 and Table 3 about here>>

Examining unadjusted expenditure shares, we find that the greatest difference in expenditure patterns between smoking and nonsmoking households is housing expenditures, with non-smoking households spending more on housing. In the all income sample, nonsmoking families spend an 8 percent greater budget share on housing. This difference is even greater (12 percent) in the low income sample. As expected, smoking households spend more on alcohol than non-smoking households. In terms of expenditure shares, smokers devote almost two times greater budget share to alcohol compared with nonsmokers (1.4\% versus $0.74 \%)$. For the lowincome group, smokers devote more than two times greater budget share to alcohol $(1.2 \%$ versus $0.5 \%$ ) than the nonsmokers.

\section{$\underline{\text { AIDS estimates }}$}

We next estimate the AIDS model using the CES (1995-2001) data. We specifically consider three samples: all households, smoking households, and all low-income households. Table 4 contains the uncompensated own price and cross price elasticities for the seven expenditure categories considered, with the diagonals indicating the own price elasticities. Standard errors are in parentheses and elasticities that are statistically significant $(\mathrm{p}<.10)$ are bold. Considering the full sample (Table 4), in most cases own price elasticities are negative and statistically significant. We estimate tobacco own price elasticity to be -0.986 . This estimate 
does not change much in the low income sample (-.946). In the smoking sample it appears less elastic (-.782). Due to a large number of zero responses for alcohol and tobacco consumption, we also estimated the model with a selection bias correction term in the tobacco and alcohol equations. These results were quite similar to the original model, so we don't present them here. $^{5}$

$$
<<\text { Insert Table } 4 \text { about here }>
$$

The demand system allows us to estimate not only the own-price, but also the cross-price elasticities; the effect that changes in the price of one category has on purchases of other categories. A positive cross-price elasticity indicates that an increase (decrease) in the price of good $i$ will cause the quantity demanded of good $j$ to increase (decrease), that is, the goods are substitutes. The tobacco cross-price elasticities (located in the tobacco column in Tables 4-6), indicate the effect on the quantity consumed of $\operatorname{good} j$ when cigarette prices change. In both the all income sample and the low income sample, we find that food is a substitute to tobacco. This suggests that when cigarette prices increase, individuals reduce tobacco consumption, and consume more food. Our estimate from the full sample suggests that when tobacco prices increase by 1 percent, the quantity of food demanded increases by 0.14 percent. In the smoking sample, there appears to be no impact of tobacco prices on food consumption.

Somewhat puzzling, in the all income sample, we find that tobacco and apparel are complements $\left(\varepsilon_{\mathrm{ij}}=-.295\right)$. When cigarette prices increase, individuals reduce both their tobacco consumption and their apparel consumption. For the low income sample, this estimate is

\footnotetext{
${ }^{5}$ For example, when we estimated the model including the selection bias correction terms, the own price elasticity of tobacco in the full sample was -.977, compared with -.986 when we did not include them.
} 
positive, much smaller and not significant $\left(\varepsilon_{\mathrm{ij}}=.133\right)$, and for the smoking sample it is almost zero $\left(\varepsilon_{\mathrm{ij}}=-.008\right)$. In the low income sample, we find that housing is a complement to tobacco. As the price of tobacco increases, low income households spend less on housing $\left(\varepsilon_{\mathrm{ij}}=-.136\right)$. This estimate is close to zero in both the all income sample $\left(\varepsilon_{\mathrm{ij}}=-.039\right)$ and the smoking sample $\left(\varepsilon_{\mathrm{ij}}=+.028\right)$.

We also find that the price of goods other than tobacco may impact tobacco purchases. To examine the effect on quantity of cigarettes purchased in response to other good price changes, we consider the estimates in the tobacco rows in Table 4. Our estimates indicate that when the price of health care increases, the quantity of tobacco consumed declines. This estimate is significant in the full sample $\left(\varepsilon_{\mathrm{ij}}=-.524\right)$, the low income sample $\left(\varepsilon_{\mathrm{ij}}=-1.191\right)$ and the smoking sample $\left(\varepsilon_{\mathrm{ij}}=-1.163\right)$.

We find that when the price of housing increases, the quantity of tobacco declines. This effect is significant in the full sample $\left(\varepsilon_{\mathrm{ij}}=-828\right)$ and the smoking sample $\left(\varepsilon_{\mathrm{ij}}=-1.256\right)$. In the low income sample it is not significant, but the estimate is suggestive of an effect $\left(\varepsilon_{\mathrm{ij}}=-1.419, \mathrm{t}-\right.$ statistic=1.62). Since we report uncompensated elasticities, we cannot distinguish whether this is an income or substitution effect. Because housing represents a large budget share, we may be capturing an income effect.

\section{Discussion}

We present a unique look at smoking households using expenditure data from a U.S. national survey of households from 1995-2001. The descriptive data explicitly compare smoking households to non-smoking households, suggesting the average differences in expenditure patterns between the two groups. In contrast, the Almost Ideal Demand System 
analysis is a marginal analysis estimating changes in expenditures due to small changes in price across multiple categories of consumer goods. It is important to note that these effects are likely to be different except in the relatively few cases where an individual quits smoking in response to a small price change. In an effort to better understand which goods families forgo for smokers to maintain their smoking habit, we estimate the cross and own price elasticities for tobacco with respect to other expense categories. We estimate a demand functional form, the Almost Ideal System, that has the advantage of being a flexible form easy to estimate, a good first order approximation to any demand system and it guarantees that the estimated coefficients are in accordance to the basic principles of consumer theory.

In the descriptive results, our finding that, regardless of income level, smoking households always spend more on alcohol than non-smoking households is consistent with the literature, which indicates smoking and drinking are positively correlated (Bien and Burge, 1990). In both the full and low-income sample, nonsmoking households spend considerably more $(33.5 \%$ versus $30.9 \%$ budget share) than smoking households on housing. A simple conclusion drawn from this relationship would be that smoking is in part maintained through lowered housing consumption.

\section{Demand model estimates—own price elasticity}

While the own price elasticity estimate for tobacco of -.986 is outside of consensus range $(-.3$ to -.5$)$, it is still well within the wider reported range in the literature $(-0.14$ to -1.23$)$ (Chaloupka and Warner, 2000). The estimate for the full sample includes both participation effects (decisions to quit/initiate smoking) and consumption effects (decisions among smokers to reduce quantity smoked). Thus, we expect the price elasticity estimates to be lower in the 
smoking sample, which only includes consumption effects. The conditional elasticity estimates for the smoking group are smaller but remain quite high at -.78. Due to limitations of these data, these results should be interpreted with caution. Because we lack information regarding the quantity smoked, to the extent that expenditure data do not reveal within category substitutions, the elasticity estimates will be biased. For instance, if changes in expenditure patterns are due in part to moves toward less expensive or longer cigarettes, this will likely overstate the estimated elasticity effects (Evans and Farrelly, 1998)

That the estimates presented here are larger than consensus estimates is puzzling. Yet, the estimates of the tobacco price elasticity presented here deviate from the literature in several important ways. Recent tax increases on cigarettes in many states in the U.S. have been considerable. Given that most of the previous estimates were from lower price points, it is entirely plausible (and perhaps to be expected) that elasticity estimates at different points on the demand curve would differ. Interestingly, behavioral economics research suggests that as the price of cigarettes increases, the price elasticity of demand rises (DeGrandpre and Bickel, 1995). Another possibility is that not all earlier estimates have controlled for tobacco control policy and variation across states in public sentiment about tobacco, particularly studies that rely solely on cross-sectional variation. Our inclusion of state fixed effects mitigates this factor and could partially explain our finding as somewhat counterintuitively, Ohsfeldt et al. (1999) found that elasticity demand estimates were larger after controlling for these other factors. A final discrepancy is our elimination of households with multiple consumer units. If these households are those least likely to change behavior in response to price changes, our elasticity estimates will be biased upwards (in absolute value).

\section{Demand model estimates-cross price elasticity}


For the full sample we find that two cross-price elasticity estimates with respect to tobacco are significant. In the full sample, tobacco and food are substitutes, although the lack of a finding for the smoking sample suggests that the effect predominantly operates through a participation effect. In other words, those who quit smoking following an increase in the price of cigarettes are most likely to increase their food consumption. Research has shown that smokers put on an average of 6.4 pounds after quitting smoking (Klesges, Meyers et al. 1989). This substitution pattern between food and cigarettes accords with increased weight gain post cessation.

According to the full sample estimates, we also find that smoking and apparel are complements. This indicates that as cigarette prices increase, consumption of apparel declines. However, this finding is not robust across samples. In general, it is also difficult to understand this effect as with such broad expenditure categories, we cannot say which type of apparel is affected.

The cross price elasticity estimates between tobacco and alcohol deserve special consideration. The effect of cigarette taxation on alcohol consumption may be of particular interest to policy makers attempting to affect positive behavioral change. Somewhat surprising, our estimates of the relationship between tobacco prices and alcohol consumption are not significant although alcohol price does affect significantly tobacco consumption.

That the quantity of tobacco consumed declines as the price of health care increases also deserves further attention. It is important to remember that in these data the health care expenditures include only out-of-pocket expenditures (not premiums paid by employers or health care costs paid by insurers). Yet, because most health insurance policies include copayments, particularly for prescription drugs, Americans are not fully insulated from the costs of care. 
Perhaps as households see the price of their health care share increasing, they associate smoking with higher future health care needs, and respond by reducing their smoking consumption. This finding makes some intuitive sense, as smokers could internalize even higher potential medical costs associated with continued smoking.

\section{Limitations}

There are potential limitations with the methods used here that limit the ability to interpret results in a way that is useful from a policy perspective. In particular, the broad range of the expenditure categories could allow a great deal of substitution within categories to be masked. Concerning the data, we have not corrected for intrastate difference in cigarette prices. Self-reported expenditure data may be biased, particularly with respect to purchases by youth living with their parents. Nevertheless, we emphasize the ability of this model to explicitly document the opportunity costs of smoking. That is, that households must necessarily forego some goods to maintain their smoking habit.

Our primary interest was to identify how households alter consumption behavior following changes in the price of cigarettes. This research is particularly important now. Many states in the U.S. have greatly increased cigarette taxes in recent years. In response, cigarette manufacturers and some commentators have argued that the resulting high cigarette prices put an undue burden on low income families. A better understanding of precisely how families are affected will shed light on this claim. Our estimates indicate that the increase in expenditure on cigarettes resulting from a price increase is not as large as expected due to the large negative own price elasticity. Therefore, the crowd-out of other goods might not be as substantial as originally anticipated. Nevertheless, we do find that increases in cigarette prices do affect negatively 
consumption of food and housing for low income families and we believe that these effects are worth taking into account when making policy. Note that the elasticities we report are uncompensated, therefore, we cannot distinguish to which extent these effects are driven by the income effect or the pure substitution effect caused by increased cigarette prices. A priori, one would expect that the negative effect on housing expenditure is due mostly to the income effect and the negative effect on food consumption to the substitution, but this is speculative and only compensated elasticities can inform us about this issue in view of designing 'compensating' policies.

In any case, we believe that a better understanding by the public of the level of spending necessary to maintain a tobacco addiction might influence some individuals never to start smoking. And, a better understanding of the goods foregone due to the purchase of tobacco may motivate some smokers to quit or motivate family members to encourage smokers to quit and might even be woven into existing treatments. This information may also be important for developing new treatments.

There are several future extensions of this project. The idea was to prevent a framework for understanding some opportunity costs of smoking. In that spirit, only broad categories of expenditure categories were included. It would be interesting to use these preliminary estimates to study more distinct classification of expenditures. For example, one might consider insurance premiums separately from other health care spending, food at home separately from food away from home, or children's clothing separately from clothing for adults. Specific family types may be important to study for policy reasons. Ultimately it will also be interesting to investigate the role that other tobacco control policies play in these relationships.

\section{Acknowledgments}


We would like to acknowledge financial support from the Robert Wood Johnson Foundation (\#039787) and NIDA (NIDA RO1-DA14471). 


\section{References}

Barrow L and McGranahan L. The earned income credit and durable goods purchases. Evanston, IL: The Joint Center for Poverty Research Conference on the Earned Income Tax Credit. 1999.

Bien, Thomas H. and Roann Burge [1990], "Smoking and Drinking: A Review of the Literature," The International Journal of the Addictions, Vol. 25, No. 12, pp.1429-1431.

Centers for Disease Control and Prevention, Division of Adult and Community Health, National Center for Chronic Disease Prevention and Health Promotion, Behavioral Risk Factor Surveillance System Online Prevalence Data, 1995-2002.

Congressional Budget Office. Federal Taxation of Tobacco, Alcoholic Beverages, and Motor Fuels. Washington, DC: U.S. Government Printing Office; 1990.

Chaloupka FJ and Warner KE. The economics of smoking. In: Culyer AJ and Newhouse JP, eds. Handbook of Health Economics, Volume 1. Elsevier Science; 2000:1539-1627.

Deaton, Angus and John Muellbauer. An Almost Ideal Demand System. The American Economic Review. June 1980. p312-326.

Deaton, Angus and John Muellbauer. Economics and Consumer Behavior. Cambridge University Press (1980b).

Decker, SL and AE Schwartz. Cigarettes and Alcohol: Substitutes or Complements? National Bureau of Economics Research Working Paper no. 75352000.

DeGrandpre RJ and WK Bickel (1995). Human Drug Self administration in a medium of exchange. Experimental and Clinical Psychopharmacology 3:349-357.

Evans WN and MC Farrelly (1998). The compensating behavior of smokers: Taxes, tar and nicotine." RAND Journal of Economics 29(3) 578-595.

Farrelly MC and JW Bray (1998). Respone to Increases in Cigarette Prices by Race/Ethnicity Income and Age Groups-United States, 1976-1993. JAMA December 16, 1998. Volume 280. No 23.

Hunt-McCool, Janet, BF Kiker and Ying Chu Ng. Estimates of the Demand for Medical Care under Different Functional Forms. Journal of Applied Econometrics. Vol 9. No 2. p201-218, 1994.

Jones, Andrew M. [1989], "A Systems Approach To The Demand For Alcohol and Tobacco," Bulletin of Economic Research, Vol. 41, No. 2, April, pp. 85-105.

Lazear EP and RT Michael. Allocation of Income Within the Household. University of Chicago Press, Chicago, IL. 1988 
Klesges RC, Meyers AW, Klesges LM, La Vasque ME. "Smoking, body weight, and their effects on smoking behavior: a comprehensive review of the literature". Psychological Bulletin 1989;106(2):204-30.

MacKay J and Erickson M, The Tobacco Atlas, World Health Organization, 2002.

Ohsfeldt, RL, RG Boyle and EI Capilouto. Tobacco taxes, smoking restrictions, and tobacco use", in: FJ Chaloupka, M Grossman, WK Bickel and H Saffer, eds. The Economic Analysis of Substance Use and Abuse: An Integration of Econometric and Behavioral Economic Research University of Chicago Press, Chicago, IL. 1999.

Remler, DK. Poor Smokers, Poor Quitters, and Cigarette Tax Regressivity. American Journal of Public Health. Volume 94(2) February 2004. p 225.

Souleles NS. The response of household consumption to income tax refunds. The American Economic Review. 1999;89(4):947-958.

The World Bank. Curbing the Epidemic: Governments and the Economics of Tobacco Control. Washington DC, 1999.

Townsend J, Roderick P, and Cooper J. Cigarette smoking by socioeconomic group, sex, and age: Effects of price, income, and health publicity. British Medical Journal. 1994;309:923-927.

U.S. Dept. of Labor, Bureau of Labor Statistics. Consumer Expenditure Survey: Interview Survey and detailed expenditure files. Washington, DC: U.S. Dept. of Labor, Bureau of Labor Statistics [producer], 2002. Ann Arbor, MI: Interuniversity Consortium for Political and Social Research, 2002.

World Health Organization. Tobacco and Poverty: A vicious circle. 2004. 
Table 1: Descriptive statistics of household and household head, CES 1995-2001 ${ }^{(1,4)}$

\begin{tabular}{|c|c|c|c|}
\hline & Full Sample ${ }^{(2)}$ & Smokers & Low Income ${ }^{(3)}$ \\
\hline $\mathrm{N}$ & 91486 & 29704 & 24748 \\
\hline Mean age of referent (years) & 41 & 42 & 39 \\
\hline \multicolumn{4}{|l|}{ Race } \\
\hline White & $82 \%$ & 84 & 73 \\
\hline Black & 13 & 11 & 22 \\
\hline Other & 5 & 4 & 6 \\
\hline Female & $42 \%$ & 40 & 46 \\
\hline \multicolumn{4}{|l|}{ Education } \\
\hline Some High School & $14 \%$ & 17 & 31 \\
\hline High school diploma & 59 & 68 & 60 \\
\hline Bachelors degree & 18 & 12 & 7 \\
\hline Graduate & 9 & 4 & 3 \\
\hline \multicolumn{4}{|l|}{ Region } \\
\hline Northeast & 19 & 20 & 18 \\
\hline Midwest & 23 & 26 & 18 \\
\hline South & 32 & 33 & 36 \\
\hline West & 26 & 21 & 29 \\
\hline Married & $57 \%$ & 56 & 51 \\
\hline $\begin{array}{l}\text { HH includes persons under } \\
18\end{array}$ & 48 & 48 & 73 \\
\hline HH includes persons over 64 & 3 & 3 & 4 \\
\hline Family Size (mean) & 2.78 & 2.84 & 3.5 \\
\hline
\end{tabular}

Notes:

(1) General sample excludes households with more than one consumer unit and households with household head not between age 18 and 65 .

(2) Sample excludes top and bottom 5th percentile of spenders.

(3) Low income is defined as reporting an income less than 200 percent of the federal poverty line.

(4) Quarterly expenditures are multiplied by 4 to report annual expenditures. 
Table 2: Average expenditures for smoking and non-smoking households, by income, CES, 1995-2001 ${ }^{(1,4)}$

\begin{tabular}{|c|c|c|c|c|c|c|}
\hline & \multicolumn{3}{|c|}{ All Income ${ }^{(2)}$} & \multicolumn{3}{|c|}{ Low income ${ }^{(3)}$} \\
\hline & $\begin{array}{c}\text { Full } \\
\text { Sample }\end{array}$ & $\begin{array}{c}\text { Smoking } \\
\text { house- } \\
\text { holds }\end{array}$ & $\begin{array}{c}\text { Non- } \\
\text { smoking } \\
\text { house- } \\
\text { holds }\end{array}$ & $\begin{array}{c}\text { Full } \\
\text { Sample }\end{array}$ & $\begin{array}{c}\text { Smoking } \\
\text { house- } \\
\text { holds }\end{array}$ & $\begin{array}{c}\text { Non- } \\
\text { smoking } \\
\text { house- } \\
\text { holds }\end{array}$ \\
\hline Tobacco & $\$ 338$ & $\$ 1041$ & $\$ 0$ & $\$ 362$ & $\$ 1018$ & $\$ 0$ \\
\hline Food & 5322 & 5338 & $5314 * * *$ & 4668 & 4773 & $4610 * *$ \\
\hline Alcohol & 323 & 443 & $265 * * *$ & 173 & 261 & $124 * * *$ \\
\hline Housing & 12145 & 11275 & $12569 * * *$ & 8925 & 8641 & $9082 * * *$ \\
\hline Apparel & 1560 & 1505 & $1587 * * *$ & 1168 & 1138 & $1184 * * *$ \\
\hline Transportation & 7758 & 7632 & $7523 * * *$ & 4946 & 5030 & $4900 * *$ \\
\hline Health care & 1565 & 1529 & 1583 & 1050 & 1056 & 1046 \\
\hline All other goods & 8741 & 7819 & $8785 * * *$ & 3638 & 3645 & 3634 \\
\hline Total expenditures & $\$ 37283$ & $\$ 36581$ & $\$ 37621$ & $\$ 24,930$ & $\$ 25,563$ & $\$ 24,581$ \\
\hline $\mathrm{N}(\%)$ & 91486 & $\begin{array}{c}29704 \\
(32.5 \%)\end{array}$ & $\begin{array}{c}61782 \\
(67.5 \%)\end{array}$ & 24748 & $\begin{array}{c}8811 \\
(35.6 \%) \\
\end{array}$ & $\begin{array}{c}15973 \\
(64.4 \%) \\
\end{array}$ \\
\hline
\end{tabular}

Notes:

(1) General sample excludes households with more than one consumer unit and households with household head not between age 18 and 65 .

(2) Sample excludes top and bottom 5th percentile of spenders.

(3) Low income is defined as reporting an income less than 200 percent of the federal poverty line.

(4) Quarterly expenditures are multiplied by 4 to report annual expenditures.

(5) Significance test controls for total expenditures.

(6) $* * * p<.01, * * p<.05$, smokers versus non-smokers. 
Table 3: Average expenditure share for smoking and non-smoking households, by income, CES, 1995-2001 $(1,2,5)$

\begin{tabular}{|c|c|c|c|c|c|c|}
\hline & \multicolumn{3}{|c|}{ All Income ${ }^{(3)}$} & \multicolumn{3}{|c|}{ Low income ${ }^{(4)}$} \\
\hline & $\begin{array}{c}\text { Full } \\
\text { Sample }\end{array}$ & $\begin{array}{c}\text { Smoking } \\
\text { house- } \\
\text { holds }\end{array}$ & $\begin{array}{c}\text { Non- } \\
\text { smoking } \\
\text { house- } \\
\text { holds }\end{array}$ & $\begin{array}{c}\text { Full } \\
\text { Sample }\end{array}$ & $\begin{array}{c}\text { Smoking } \\
\text { house- } \\
\text { holds }\end{array}$ & $\begin{array}{c}\text { Non- } \\
\text { smoking } \\
\text { house- } \\
\text { holds }\end{array}$ \\
\hline Tobacco & $1.26 \%$ & $3.77 \%$ & $0 \%$ & $1.8 \%$ & $5.1 \%$ & $0 \%$ \\
\hline Food & 16.9 & 17.1 & $16.7 * * *$ & 22.1 & 21.5 & $22.3 * * *$ \\
\hline Alcohol & 0.95 & 1.37 & $0.75 * * *$ & 0.7 & 1.2 & $0.5 * * *$ \\
\hline Housing & 35.4 & 33.6 & $36.3 * * *$ & 38.9 & 36.2 & $40.4 * * *$ \\
\hline Apparel & 4.3 & 4.2 & $4.4 * * *$ & 4.8 & 4.5 & $5.0 * * *$ \\
\hline Transportation & 15.2 & 15.4 & $15.1 * *$ & 13.8 & 14.1 & $13.6^{* * *}$ \\
\hline Health care & 4.3 & 4.2 & $4.4 * * *$ & 3.4 & 3.8 & 4.1 \\
\hline Miscellaneous & 21.7 & 20.4 & $22.4 * * *$ & 13.9 & 13.7 & 14.1 \\
\hline Total & $100 \%$ & $100 \%$ & $100 \%$ & $100 \%$ & $100 \%$ & $100 \%$ \\
\hline $\mathbf{N}(\%)$ & 91486 & $\begin{array}{c}29704 \\
(32.5 \%)\end{array}$ & $\begin{array}{c}61782 \\
(67.5 \%)\end{array}$ & 24748 & $\begin{array}{c}8811 \\
(35.6 \%)\end{array}$ & $\begin{array}{c}15973 \\
(64.4 \%)\end{array}$ \\
\hline
\end{tabular}

Notes:

(1) Because total expenditures differ among households, the sum of a categories expenditures for all households divided by the sum of spending over all households does not equal the average of individual households expenditure share.

(2) General sample excludes households with more than one consumer unit and households with household head not between age 18 and 65 .

(3) Sample excludes top and bottom 5th percentile of spenders.

(4) Low income is defined as reporting an income less than 200 percent of the federal poverty line.

(5) Quarterly expenditures are multiplied by 4 to report annual expenditures.

(6) $* * * p<.01, * * p<.05$, smokers versus non-smokers. 
Table 4: Own and cross price elasticities, Full Sample CES, 1995-2001 (N=91,486)

Price

\begin{tabular}{|c|c|c|c|c|c|c|c|c|}
\hline $\mathbf{Q}$ & Tobacco & Food & Housing & Apparel & $\begin{array}{c}\text { Trans- } \\
\text { portation }\end{array}$ & $\begin{array}{c}\text { Health } \\
\text { care }\end{array}$ & Alcohol & $\begin{array}{c}\text { All other } \\
\text { goods }\end{array}$ \\
\hline Tobacco & $\begin{array}{c}-.986 * * \\
(.035)\end{array}$ & $\begin{array}{c}.294 \\
(.263)\end{array}$ & $\begin{array}{c}-.828 * * \\
(.318)\end{array}$ & $\begin{array}{l}-.071 \\
(.074)\end{array}$ & $\begin{array}{l}-.303 \\
(.194)\end{array}$ & $\begin{array}{c}-.524 * * \\
(.146)\end{array}$ & $\begin{array}{l}-.066 \\
(.263)\end{array}$ & $\begin{array}{c}1.981 * * \\
(.952)\end{array}$ \\
\hline Food & $\begin{array}{l}.144 * * \\
(.043)\end{array}$ & $\begin{array}{c}-1.045 * * \\
(.314) \\
\end{array}$ & $\begin{array}{l}-.619 \\
(.388)\end{array}$ & $\begin{array}{l}-.126 \\
(.090)\end{array}$ & $\begin{array}{c}-.490 * * \\
(.237)\end{array}$ & $\begin{array}{c}-.574 * * \\
(.178)\end{array}$ & $\begin{array}{l}.147 \\
(.238)\end{array}$ & $\begin{array}{c}1.342 \\
(1.162)\end{array}$ \\
\hline Housing & $\begin{array}{c}-.039 \\
(.030)\end{array}$ & $\begin{array}{l}.841 * * \\
(.229) \\
\end{array}$ & $\begin{array}{l}-.355 \\
(.276)\end{array}$ & $\begin{array}{l}.127 * * \\
(.064)\end{array}$ & $\begin{array}{l}.447 * * \\
(.169)\end{array}$ & $\begin{array}{l}.172 \\
(.126)\end{array}$ & $\begin{array}{l}-.333 \\
(.212)\end{array}$ & $\begin{array}{l}-.253 \\
(.827)\end{array}$ \\
\hline Apparel & $\begin{array}{c}-.295 * * \\
(.101)\end{array}$ & $\begin{array}{c}-2.841 * * \\
(.759) \\
\end{array}$ & $\begin{array}{l}.641 \\
(.916)\end{array}$ & $\begin{array}{c}-.974 * * \\
(.212)\end{array}$ & $\begin{array}{l}-.471 \\
(.560)\end{array}$ & $\begin{array}{l}-.168 \\
(.420)\end{array}$ & $\begin{array}{c}1.188 * * \\
(.576)\end{array}$ & $\begin{array}{c}3.930 \\
(2.745)\end{array}$ \\
\hline Transportation & $\begin{array}{l}.054 \\
(.083)\end{array}$ & $\begin{array}{c}-2.205 * * \\
(.627)\end{array}$ & $\begin{array}{r}-1.222 \\
(.756)\end{array}$ & $\begin{array}{l}-.200 \\
(.176)\end{array}$ & $\begin{array}{c}1.819 * * \\
(.462)\end{array}$ & $\begin{array}{l}-.421 \\
(.347)\end{array}$ & $\begin{array}{l}.793 * \\
(.475)\end{array}$ & $\begin{array}{c}3.602 \\
(2.267)\end{array}$ \\
\hline Healthcare & $\begin{array}{l}-.129 \\
(.523)\end{array}$ & $\begin{array}{l}-1.041 \\
(.946)\end{array}$ & $\begin{array}{l}-1.381 \\
(1.141)\end{array}$ & $\begin{array}{l}.486 * * \\
(.265)\end{array}$ & $\begin{array}{c}-1.419 * * \\
(.697)\end{array}$ & $\begin{array}{c}-1.557 * * \\
(.523)\end{array}$ & $\begin{array}{l}-.613 \\
(.717)\end{array}$ & $\begin{array}{c}\text { 6.700*** } \\
(3.420)\end{array}$ \\
\hline Alcohol & $\begin{array}{l}.028 \\
(.082)\end{array}$ & $\begin{array}{c}.310 \\
(.619)\end{array}$ & $\begin{array}{l}-.114 \\
(.747)\end{array}$ & $\begin{array}{l}.117 \\
(.174)\end{array}$ & $\begin{array}{l}-.361 \\
(.457)\end{array}$ & $\begin{array}{l}.507 \\
(.343)\end{array}$ & $\begin{array}{c}-1.921 * * \\
(.470)\end{array}$ & $\begin{array}{c}1.74 \\
(2.240)\end{array}$ \\
\hline
\end{tabular}

Notes:

(1) Standard errors in parentheses.

(2) General sample excludes households with more than one consumer unit and households with household head not between age 18 and 65 .

(3) Sample excludes top and bottom 5th percentile of spenders.

(4) Model controls for age, race, education, presence of household members less than age 18, presence of family members over age 64, state fixed effects, region fixed effects, urban/rural, month of interview, year, marital status, and family size.

(5) These estimates use the conditional expenditure shares to calculate alcohol and cigarettes elasticity.

(6) Elasticity estimates where $\mathrm{p}<.10$ are bold.

(7) $* * p<.05, * p<.10$ 
Table 5: Own and cross price elasticities, Smoking Sample, CES, 1995-2001 (N=29,704)

Price

\begin{tabular}{|c|c|c|c|c|c|c|c|c|}
\hline $\mathbf{Q}$ & Tobacco & Food & Housing & Apparel & $\begin{array}{l}\text { Trans- } \\
\text { portation }\end{array}$ & $\begin{array}{c}\text { Health } \\
\text { care }\end{array}$ & Alcohol & $\begin{array}{l}\text { All other } \\
\text { goods }\end{array}$ \\
\hline Tobacco & $\begin{array}{c}-0.782 \\
(0.074)\end{array}$ & $\begin{array}{c}-0.867 \\
(0.534) \\
\end{array}$ & $\begin{array}{c}-1.256^{*} \\
(0.633)\end{array}$ & $\begin{array}{l}-0.069 \\
(0.148)\end{array}$ & $\begin{array}{l}-0.169 \\
(0.392)\end{array}$ & $\begin{array}{l}-1.163 * \\
(0.286)\end{array}$ & $\begin{array}{l}-0.226^{*} \\
(0.409)\end{array}$ & $\begin{array}{c}3.015 \\
(1.900)\end{array}$ \\
\hline Food & $\begin{array}{c}0.010 \\
(0.077)\end{array}$ & $\begin{array}{c}-0.105 \\
(0.556)\end{array}$ & $\begin{array}{c}-0.022 \\
(0.659)\end{array}$ & $\begin{array}{c}0.118 \\
(0.154)\end{array}$ & $\begin{array}{c}-0.836 * * \\
(0.408)\end{array}$ & $\begin{array}{l}-0.317 \\
(0.297)\end{array}$ & $\begin{array}{l}-0.042 \\
(0.426)\end{array}$ & $\begin{array}{c}0.604 \\
(1.977)\end{array}$ \\
\hline Housing & $\begin{array}{c}0.028 \\
(0.066)\end{array}$ & $\begin{array}{c}1.066 * * \\
(0.475) \\
\end{array}$ & $\begin{array}{l}-0.316 \\
(0.563)\end{array}$ & $\begin{array}{c}0.210 \\
(0.131)\end{array}$ & $\begin{array}{l}0.603 * \\
(0.349)\end{array}$ & $\begin{array}{c}0.345 \\
(0.254)\end{array}$ & $\begin{array}{l}-0.701 * \\
(0.364)\end{array}$ & $\begin{array}{c}-2.272 \\
(1.691)\end{array}$ \\
\hline Apparel & $\begin{array}{l}-0.008 \\
(0.181)\end{array}$ & $\begin{array}{c}-0.878 \\
(1.313) \\
\end{array}$ & $\begin{array}{l}-1.450 \\
(1.556)\end{array}$ & $\begin{array}{c}-0.685^{*} \\
(0.363)\end{array}$ & $\begin{array}{l}-1.374 \\
(0.964)\end{array}$ & $\begin{array}{c}0.022 \\
(0.702)\end{array}$ & $\begin{array}{l}1.008 \\
(1.005)\end{array}$ & $\begin{array}{c}6.408 \\
(4.770)\end{array}$ \\
\hline Transportation & $\begin{array}{l}-0.066 \\
(0.154)\end{array}$ & $\begin{array}{c}-3.343 * * \\
(1.111) \\
\end{array}$ & $\begin{array}{c}-0.185 \\
(1.318)\end{array}$ & $\begin{array}{c}-\mathbf{- 0 . 5 8 3} * \\
(0.307)\end{array}$ & $\begin{array}{c}0.669 \\
(0.816)\end{array}$ & $\begin{array}{l}-0.606 \\
(0.594)\end{array}$ & $\begin{array}{c}0.772 \\
(0.851)\end{array}$ & $\begin{array}{l}-0.547 \\
(3.953)\end{array}$ \\
\hline Healthcare & $\begin{array}{l}-0.075 \\
(0.869)\end{array}$ & $\begin{array}{c}-0.580 \\
(1.625) \\
\end{array}$ & $\begin{array}{c}-2.581 \\
(1.927)\end{array}$ & $\begin{array}{c}-0.453 \\
(0.450)\end{array}$ & $\begin{array}{l}-2.264^{*} \\
(1.193)\end{array}$ & $\begin{array}{c}-0.880 \\
(0.869)\end{array}$ & $\begin{array}{l}-2.002 \\
(1.245)\end{array}$ & $\begin{array}{c}9.408 \\
(5.782)\end{array}$ \\
\hline Alcohol & $\begin{array}{c}0.015 \\
(0.195)\end{array}$ & $\begin{array}{c}-0.582 \\
(1.408)\end{array}$ & $\begin{array}{c}0.098 \\
(1.669)\end{array}$ & $\begin{array}{l}-0.461 \\
(0.389)\end{array}$ & $\begin{array}{c}-0.661 \\
(1.033)\end{array}$ & $\begin{array}{l}-0.220 \\
(0.753)\end{array}$ & $\begin{array}{c}-0.983 \\
(1.078)\end{array}$ & $\begin{array}{c}2.169 \\
(5.007)\end{array}$ \\
\hline
\end{tabular}

Notes:

(1) Standard errors in parentheses.

(2) General sample excludes households with more than one consumer unit and households with household head not between age 18 and 65 .

(3) Sample excludes top and bottom 5th percentile of spenders.

(4) Model controls for age, race, education, presence of household members less than age 18, presence of family members over age 64, state fixed effects, region fixed effects, urban/rural, month of interview, year, marital status, and family size.

(5) These estimates use the conditional expenditure shares to calculate alcohol and cigarettes elasticity.

(6) Elasticity estimates where $\mathrm{p}<.10$ are bold.

(7) $* * p<.05, * p<.10$ 
Table 6: Own and cross price elasticities, low income sample, CES, 1995-2001 (N=24,748)

\begin{tabular}{|c|c|c|c|c|c|c|c|c|}
\hline \multicolumn{9}{|c|}{ Price } \\
\hline $\mathbf{Q}$ & Tobacco & Food & Housing & Apparel & $\begin{array}{c}\text { Trans- } \\
\text { portation }\end{array}$ & $\begin{array}{c}\text { Health } \\
\text { care }\end{array}$ & Alcohol & $\begin{array}{l}\text { All other } \\
\text { goods }\end{array}$ \\
\hline Tobacco & $\begin{array}{c}-0.946 * * \\
(0.096)\end{array}$ & $\begin{array}{c}-1.696 * * \\
(0.711) \\
\end{array}$ & $\begin{array}{l}-1.419 \\
(0.877)\end{array}$ & $\begin{array}{l}-0.010 \\
(0.198)\end{array}$ & $\begin{array}{c}-1.123 * * \\
(0.521)\end{array}$ & $\begin{array}{c}-1.191 * * \\
(0.412)\end{array}$ & $\begin{array}{c}-1.072 * * \\
(0.533)\end{array}$ & $\begin{array}{l}\text { 7.707*** } \\
(\mathbf{2 . 6 0 5 )}\end{array}$ \\
\hline Food & $\begin{array}{c}0.131 * * \\
(0.076)\end{array}$ & $\begin{array}{c}-0.758 \\
(0.564)\end{array}$ & $\begin{array}{l}-0.553 \\
(0.696)\end{array}$ & $\begin{array}{l}-0.068 \\
(0.157)\end{array}$ & $\begin{array}{l}-0.416 \\
(0.414)\end{array}$ & $\begin{array}{c}-0.625 * * \\
(0.327)\end{array}$ & $\begin{array}{l}-0.090 \\
(0.423)\end{array}$ & $\begin{array}{c}1.202 \\
(2.069)\end{array}$ \\
\hline Housing & $\begin{array}{c}-0.136 * * \\
(0.074)\end{array}$ & $\begin{array}{c}1.418 * * \\
(0.543)\end{array}$ & $\begin{array}{c}-0.274 \\
(0.671)\end{array}$ & $\begin{array}{l}0.265^{*} \\
(0.152)\end{array}$ & $\begin{array}{c}0.396 \\
(0.398)\end{array}$ & $\begin{array}{c}0.656 * * \\
(0.315)\end{array}$ & $\begin{array}{l}-0.524 \\
(0.407)\end{array}$ & $\begin{array}{l}-3.444 \\
(1.992)\end{array}$ \\
\hline Apparel & $\begin{array}{c}0.133 \\
(0.189)\end{array}$ & $\begin{array}{c}-4.275 * * \\
(1.405) \\
\end{array}$ & $\begin{array}{c}0.756 \\
(1.733)\end{array}$ & $\begin{array}{c}-1.386 * * \\
(0.392)\end{array}$ & $\begin{array}{c}-0.371 \\
(1.030)\end{array}$ & $\begin{array}{c}-0.422 \\
(0.814)\end{array}$ & $\begin{array}{c}0.691 \\
(1.053)\end{array}$ & $\begin{array}{c}3.499 \\
(5.150)\end{array}$ \\
\hline Transportation & $\begin{array}{c}0.101 \\
(0.213)\end{array}$ & $\begin{array}{c}-4.137 * * \\
(1.578) \\
\end{array}$ & $\begin{array}{c}-2.726 \\
(1.947)\end{array}$ & $\begin{array}{c}-\mathbf{- 0 . 6 9 0} \\
(0.440)\end{array}$ & $\begin{array}{c}-1.841 \\
(1.157)\end{array}$ & $\begin{array}{c}0.085 \\
(0.914)\end{array}$ & $\begin{array}{c}2.438 * * \\
(1.183)\end{array}$ & $\begin{array}{c}5.396 \\
(5.784)\end{array}$ \\
\hline Healthcare & $\begin{array}{c}-0.600 \\
(1.860)\end{array}$ & $\begin{array}{r}-2.939 \\
(3.212) \\
\end{array}$ & $\begin{array}{c}1.205 \\
(3.963)\end{array}$ & $\begin{array}{c}0.538 \\
(0.896)\end{array}$ & $\begin{array}{c}2.065 \\
(2.355)\end{array}$ & $\begin{array}{c}-2.088 \\
(1.860)\end{array}$ & $\begin{array}{l}-3.352 \\
(2.407)\end{array}$ & $\begin{array}{c}1.215 \\
(11.773)\end{array}$ \\
\hline Alcohol & $\begin{array}{l}-0.087 \\
(0.168)\end{array}$ & $\begin{array}{c}2.651 * * \\
(1.247)\end{array}$ & $\begin{array}{l}-0.607 \\
(1.538)\end{array}$ & $\begin{array}{c}-0.252 \\
(0.348)\end{array}$ & $\begin{array}{l}-0.235 \\
(0.914)\end{array}$ & $\begin{array}{c}1.121 \\
(0.722)\end{array}$ & $\begin{array}{c}-3.569 * * \\
(0.934)\end{array}$ & $\begin{array}{c}2.755 \\
(4.570)\end{array}$ \\
\hline
\end{tabular}

Notes:

(1) Standard errors in parentheses.

(2) General sample excludes households with more than one consumer unit and households with household head not between age 18 and 65 .

(3) Low income is defined as reporting an income less than 200 percent of the federal poverty line.

(4) Model controls for age, race, education, presence of household members less than age 18, presence of family members over age 64, state fixed effects, region fixed effects, urban/rural, month of interview, year, marital status, and family size.

(5) These estimates use the conditional expenditure shares to calculate alcohol and cigarettes elasticity.

(6) Elasticity estimates where $\mathrm{p}<.10$ are bold.

(7) $* * p<.05, * p<.10$ 